\title{
Enterobiasis: threadworm infection presenting as acute appendicitis in a 13-year-old girl
}

\author{
Shohib Tariq
}

Department of Paediatrics, University Hospital of North Midlands NHS Trust, Birmingham, West Midlands, UK

\section{Correspondence to} Dr Shohib Tariq shohib.tariq@nhs.net

Accepted 29 December 2014

\section{DESCRIPTION}

A 13-year-old girl presented to A\&E with a 3-day history of abdominal pain, anorexia and nausea. Bowels were opening regularly once daily with no blood or mucous and there were no urinary symptoms.

Menstruation was normal; there was no vaginal discharge or bleeding and the patient denied being sexually active.

The pain had begun in the umbilicus and radiated to the right iliac fossa.

On examination, the patient's abdomen was soft with rebound tenderness in the right iliac fossa, epigastric and umbilical regions. During morning review, her abdomen became rigid and pain worsened.

She was afebrile, but tachycardic. Laboratory testing revealed elevated white cell counts of $14.9 \times 10^{9} / \mathrm{L}$ with neutrophilia and eosinophilia.

The signs and symptoms were highly indicative of appendicitis as the patient scored $9 / 10$ on the Alvarado appendicitis scoring scale.

A decision was made to directly prepare the patient for diagnostic laparoscopy rather than wait for imaging. During the surgery, worms were seen in the appendix.

The appendix was removed (figure 1) along with all visible worms, later identified as threadworms (figure 2).

Post appendicectomy the patient was asked about anal itching, a common symptom of threadworm infection, ${ }^{1}$ which she confirmed. The pain resolved and the patient was discharged with co-amoxiclav along with mebendazole to treat the threadworm infestation; the general practitioner was instructed to treat the family as well.

Co-amoxiclav is preferred over metronidazole as it also covers anaerobes. ${ }^{2}$ There is literature highlighting

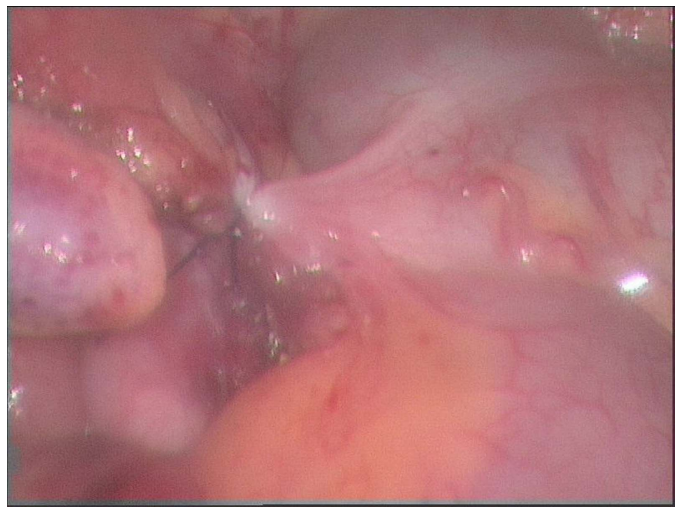

Figure 1 Photograph taken in theatre demonstrating the inflammation of the appendix caused by threadworms prior to removal during laparoscopic surgery.

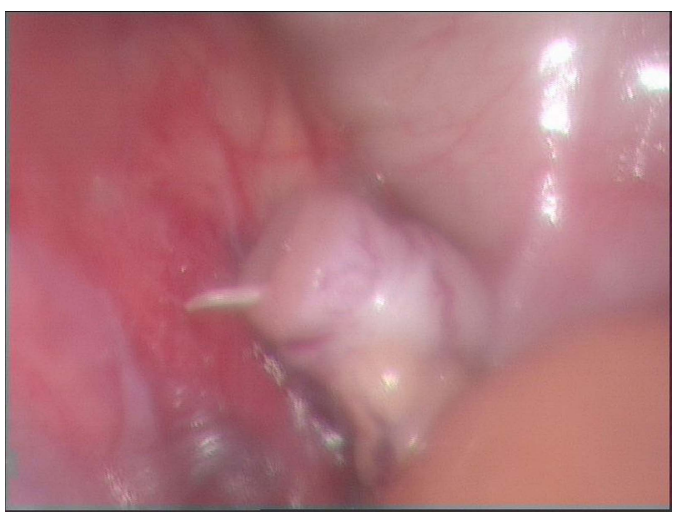

Figure 2 Threadworm protruding from the appendix during laparoscopic surgery. This was a live worm as it was moving during removal of the appendix.

the fact that a combination of metronidazole and mebendazole may cause Stevens-Johnson syndrome. ${ }^{3}$

\section{Learning points}

- If threadworms are isolated the whole family and immediate contacts should be treated as infection could otherwise reoccur and spread.

- Pruritus ani is a symptom of threadworm infection and consideration should be made to ask this in the history in this presentation.

- The Alvarado score is a useful clinical scoring system to predict the likelihood of appendicitis, however, this case shows a score as high as 9/ 10 may be due to threadworm infection mimicking appendicitis. The Alvarado score is calculated by patient symptoms, signs and blood test results in establishing the probability of acute appendicitis. The maximum score is 10 .

Competing interests None.

Patient consent Obtained.

Provenance and peer review Not commissioned; externally peer reviewed.

\section{REFERENCES}

1 Day S. Threadworm: an infrequent clinical finding in a genitourinary medicine clinic attendee presenting with ano-genital irritation. Int J STD AIDS 2009;20:362-3.

2 Drumm J, Donovan IA, Wise $R$, et al. Metronidazole and augmentin in the prevention of sepsis after appendicectomy. Br J Surg 1985;72:571-3.

3 Chen KT, Twu SJ, Chang HJ, et al. Outbreak of Stevens-Johnson syndrome/toxic epidermal necrolysis with mebendazole and metronidazole use among Filipino labourers in Taiwan. Am J Public Health 2003;93:489-92. 
Copyright 2015 BMJ Publishing Group. All rights reserved. For permission to reuse any of this content visit http://group.bmj.com/group/rights-licensing/permissions.

BMJ Case Report Fellows may re-use this article for personal use and teaching without any further permission.

Become a Fellow of BMJ Case Reports today and you can:

- Submit as many cases as you like

- Enjoy fast sympathetic peer review and rapid publication of accepted articles

- Access all the published articles

- Re-use any of the published material for personal use and teaching without further permission

For information on Institutional Fellowships contact consortiasales@bmjgroup.com

Visit casereports.bmj.com for more articles like this and to become a Fellow 